\section{Identification of high velocity anomalies, imperceptible to seismic resolution, by integration of seismic attributes, in Penobscot Field, Canada}

The Mining-Geology-Petroleum Engineering Bulletin UDC: 550.8

DOI: $10.17794 /$ rgn.2019.1.2

Original scientific paper

\author{
Wilmer Emilio García Moreno'; Iván Daniel Omaña Galeano. \\ ${ }^{1}$ Sartenejas, Baruta, Miranda State, Caracas Metropolitan District (Simón Bolivar University, 89000)
}

\begin{abstract}
Penobscot Field is located in the Sable Sub-basin, in the Nova Scotia Basin, belonging to the Canadian territory, and for the year of 1991, a 3 D seismic acquisition was carried out in this region. Also, two exploratory wells were previously drilled (L-30 and B-41). Then, with the subsequent interpretation of the area, a discrepancy was found around 10ms to $15 \mathrm{~ms}$ (approximately $25 \mathrm{~m}$ ) in the travel times of the seismic waves in the vicinity of well B-41, resulting in a false structural high in the Mississauga Formation and Naskapi Member. It is possibly caused by changes in geological facies and thickness of the Wyandot formation, consequently, B-41 well became dry. For these reasons, to identify the possible problem which caused everything mentioned above, the area between the wells was delimited by a seismic subvolume (by reducing the seismic cube), making a seismic interpretation of the top of the formations of interest, as well as an analysis of certain petrophysical properties in the wells, in order to delimit the thickness of the anomaly and, consecutively, the use of the seismic attributes for lateral identification of the anomaly in the Wyandot Formation.
\end{abstract}

Keywords:

High Velocity Anomaly; Mississauga Formation; Wyandot Formation; Naskapi Member; Seismic Attributes.

\section{Introduction}

In the hydrocarbon industry, seismic methods play a fundamental role in exploration, since they allow the study basin to be structurally and stratigraphically described (Alsadi, 2017). A proper application of these geophysical methods, whether they are used in the stage of exploration or interpretation has a crucial role because any failure can culminate in a large amount of lost money.

The Scotian Basin (offshore in the Nova Scotia region) extends over $300.000 \mathrm{~km}^{2}$ (Hansen et al., 2004), a series of tenders were awarded by the Nova Scotia Offshore Petroleum Board for the acquisition of nine areas in three geographically and geologically different areas, including Penobscot Field (Smith et al., 2015), located in the Sable Sub-basin, Canada, being a study area of approximately $66 \mathrm{~km}^{2}(5.5 \mathrm{~km} \times 12 \mathrm{~km})$ of 3D seismic acquisition.

Geologically, this region is notable for the presence of clastic and carbonate sequences, which include formations of interest for research, such as the Wyandot Formation, which is a carbonate platform of Jurassic age and the Mississauga Formation, which is a sandstone and the exploration focus is located here due to the presence of hydrocarbons.

Corresponding author: Wilmer Emilio García Moreno

Wilgm93@gmail.com
In the early exploration phase of Penobscot Field, two wells (Penobscot L-30 and Penobscot B-41) were drilled for the purpose of testing the presence of hydrocarbons in two structural heights, which are in contact with reverse faults. However, the location of these did not produce satisfactory results because the well B-41 was dry and, it was in that moment, when an advancement was found in the travel times at the Mississauga formation of approximately $15 \mathrm{~ms}$, which may be caused owing to the closing times in the interpreted time maps were not the same as the depth maps, due to, perhaps, the velocity changes in the upper strata (Campbell et al., 2015).

Due to this existing problem, mentioned above, and knowing the importance in each phase of the exploration, the present study seeks to characterize the area in question, with the purpose of discriminating the facies produced by the advancement in the travel time of the seismic waves, through an integrated interpretation of a seismic subvolume and petrophysical data, making use of seismic and multi-attribute analysis by neural networks and also observing the results when they are integrated by RGB.

\section{Geographical location of the study area}

The study area in this work is located in the Nova Scotia Basin specifically in the Sable Sub-basin, northeast of Sable Island, in a transition zone, in a passive 


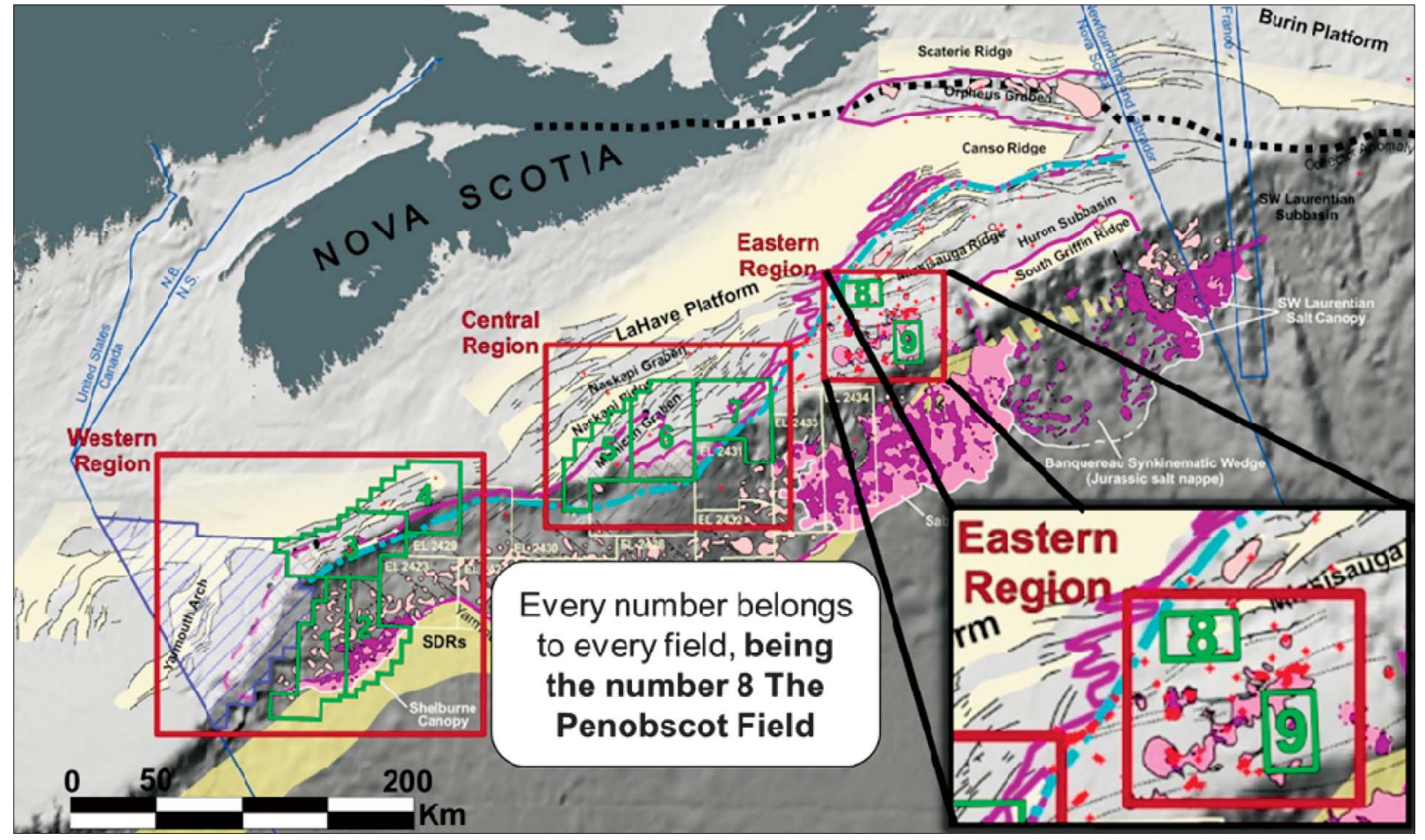

Figure 1: Location of the study area. Modified from Smith et al. (2015)

Table 1: Coordinates of the Seismic Cube of Penobscot Field, based on the Spheroid with central meridian of $-63^{\circ}$ from Clarke 1886

\begin{tabular}{|l|l|l|}
\hline Cornerssrs & North coordinate & East coordinate \\
\hline $\mathbf{P}_{\mathbf{1}}$ & 4890130.78 & 731998.45 \\
\hline $\mathbf{P}_{\mathbf{2}}$ & 4896722.05 & 728527.16 \\
\hline $\mathbf{P}_{\mathbf{3}}$ & 4895689.47 & 742633.34 \\
\hline $\mathbf{P}_{4}$ & 4802330.74 & 739162.05 \\
\hline
\end{tabular}

margin that goes from the western end of the Abenaki Basin to the north flank of the Sable Sub-basin, in parcel 8 (see Figure 1) that corresponds to the seismic cube worked and its observable coordinates in Table 1.

\section{Tectono-stratigraphic evolution of the Nova Scotia Basin}

This evolution was divided into four stages (pre-rift, syn-rift, early post-rift and late post-rift), focusing on the last phase, since the geological formations of interest for the study took place there

\subsection{Pre-Rift}

By this time, the Nova Scotia Basin consisted of a series of platforms and depocenters. The boundaries of these platforms and basins could have been defined by areas of regularly spaced oceanic fractures that extended to the surface (Welsink et al., 1989) with a trend towards the northeast, defining the limit of maximum tectonic extension and an abrupt increase in depth of the basement towards the sea, due to a thermal subsidence. All this subsequently caused the Nova Scotia Basin to begin to develop approximately 200 million years ago with the opening of the Atlantic Ocean after North America separated from the African continent during the disintegration of Pangea (Canada-Nova Scotia Offshore Petroleum Board, n.d) as illustrated in Figure 2

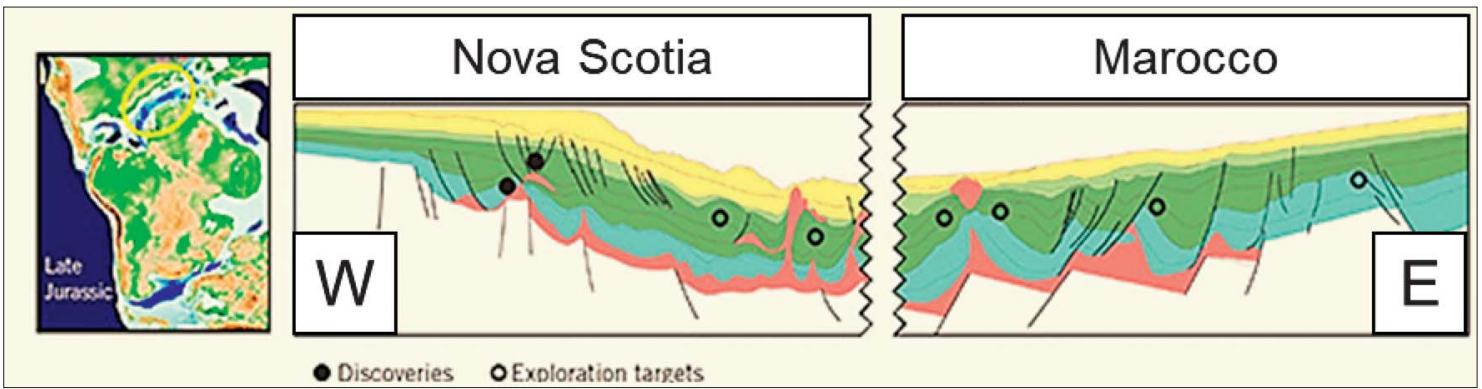

Figure 2: Similarity between the Nova Scotia and Morocco basins. Modified from http://www.ogj.com/articles/print/volume-113/issue-5/special-report-offshore-petroleum-operations/deepwater-prospects-gain-momentum-off-morocco.html (accessed 17st May 2017) 


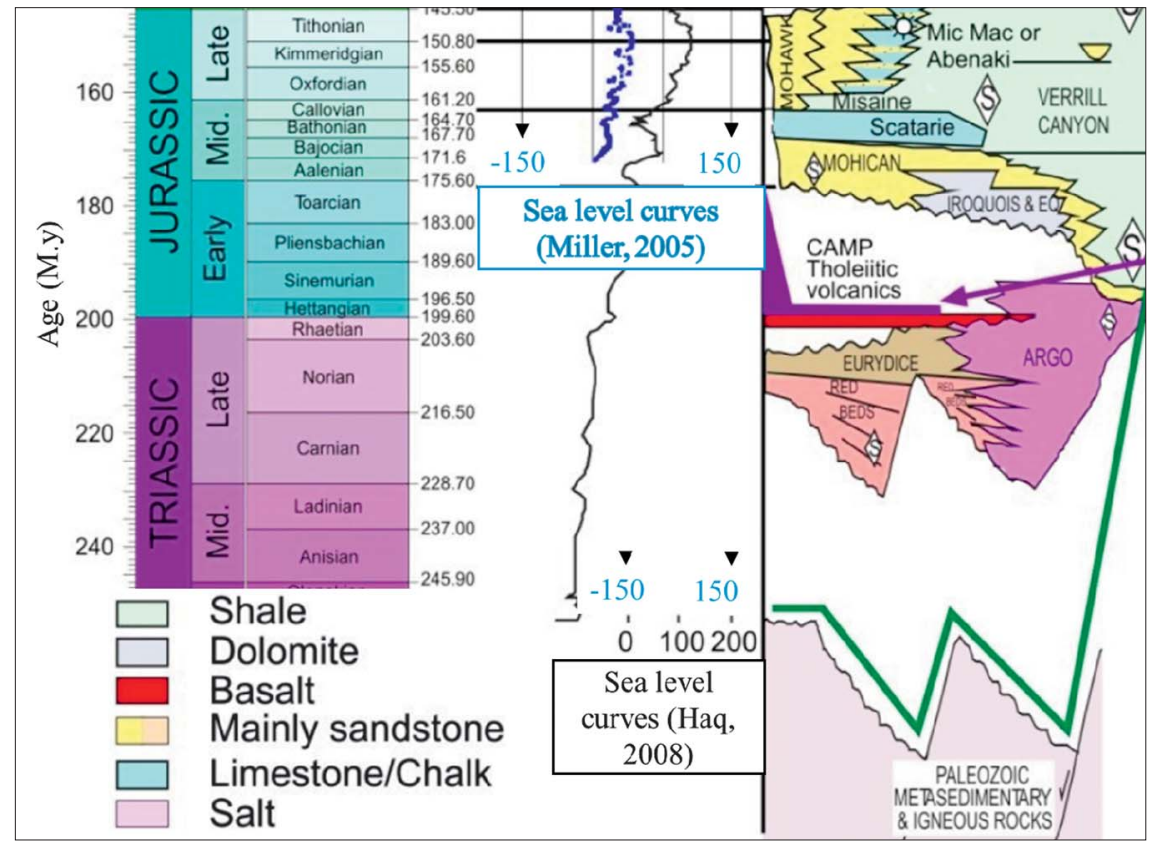

Figure 3: Lithostratigraphic column during the Triassic and Jurassic. Modified from Smith et al. (2010)

where the relationship of Northwest Africa with the Nova Scotia Basin is noted.

\subsection{Syn-Rift}

The Nova Scotia Basin was located near the centre of Pangea, adjacent to the Paleoecuador and there the sediments were deposited in a hot and arid environment. Already in the Middle Triassic, about 225 million years ago, the tensional forces oriented towards the northeast initiated the rupture of the oceanic floor, causing the sedimentation to consist of volcanic rocks associated with the rupture phase and fluvial and lacustrine sediments, which nowadays corresponds to the lower part of the Eurydice Formation (Wade \& MacLean, 1990; Albertz, et. al., 2010). On the other hand, due to the hot and dry climate, the shallow seas evaporated rapidly, which resulted in the precipitation of salt in large areas and smaller deposits of anhydrite that were up to two kilometres thick in the central parts of the rupture system (Argo Formation).

In the Late Triassic and the Early Jurassic, tectonism continued, causing the formation of a disagreement by the rupture, when North America and Africa separated completely, occurring in this period the expansion of the Tethys Sea in the Nova Scotia Basin, within from which carbonates and clastic sediments of the Iroquois Formation were deposited. This was followed by the deposition of thick clastic fluvial sediments: the Mohican Formation (McIver, 1972). During the Middle Jurassic, the basin reaches great deposit complexity (Weston, et al., 2012). This range includes the Abenaki, Mohawk, MicMac, Verrill Canyon formations and the lower member of the Mississauga Formation (see Figure 3).

\subsection{Early Post-Rift}

The combination of sea floor expansion, basin subsidence and global sea level rise caused the Atlantic Ocean to become wider and deeper $(\sim 1000 \mathrm{~m})$ in the Middle Jurassic. An important carbonate platform was developed in the western part of the basin at this time and persisted until the Upper Jurassic and Lower Cretaceous, forming for this time, the different members of the Abenaki Formation (Scatarie, Misaine and Baccaro).

During the Late Jurassic, the existing river systems cut the platform deep during the low sea level, possibly forming deltaic complexes at the edge of the platform (Kidston, et al., 2002; Weston et al., 2012) Turbidity currents, massive sediment flows and large depressions transported significant amounts of clastic sediments derived from the Mic-Mac Formation (see Figure 3).

\subsection{Late Post-Rift}

The deposition of fluvio-deltaic sediments continued in the Early Cretaceous (Barremian / Valanginian) forming the middle and upper members of the formation of the Mississauga Formation (Wade \& MacLean, 1990; Pe-Piper \& Mckay, 2006). The 'O' Marker (a diachronic, carbonated and seismic marker on the platform) separates the members of Lower Mississauga and Middle Mississauga from the top (Jansa and Noguera, 1990; Beicip-Franlab, 2011).

A reduction in sediment supply and regional transgression in the Aptian period resulted in the deposition of the Naskapi shales on the sands of the Mississauga Formation. On the other hand, that same regional transgression that began in the Early Cretaceous deposited 


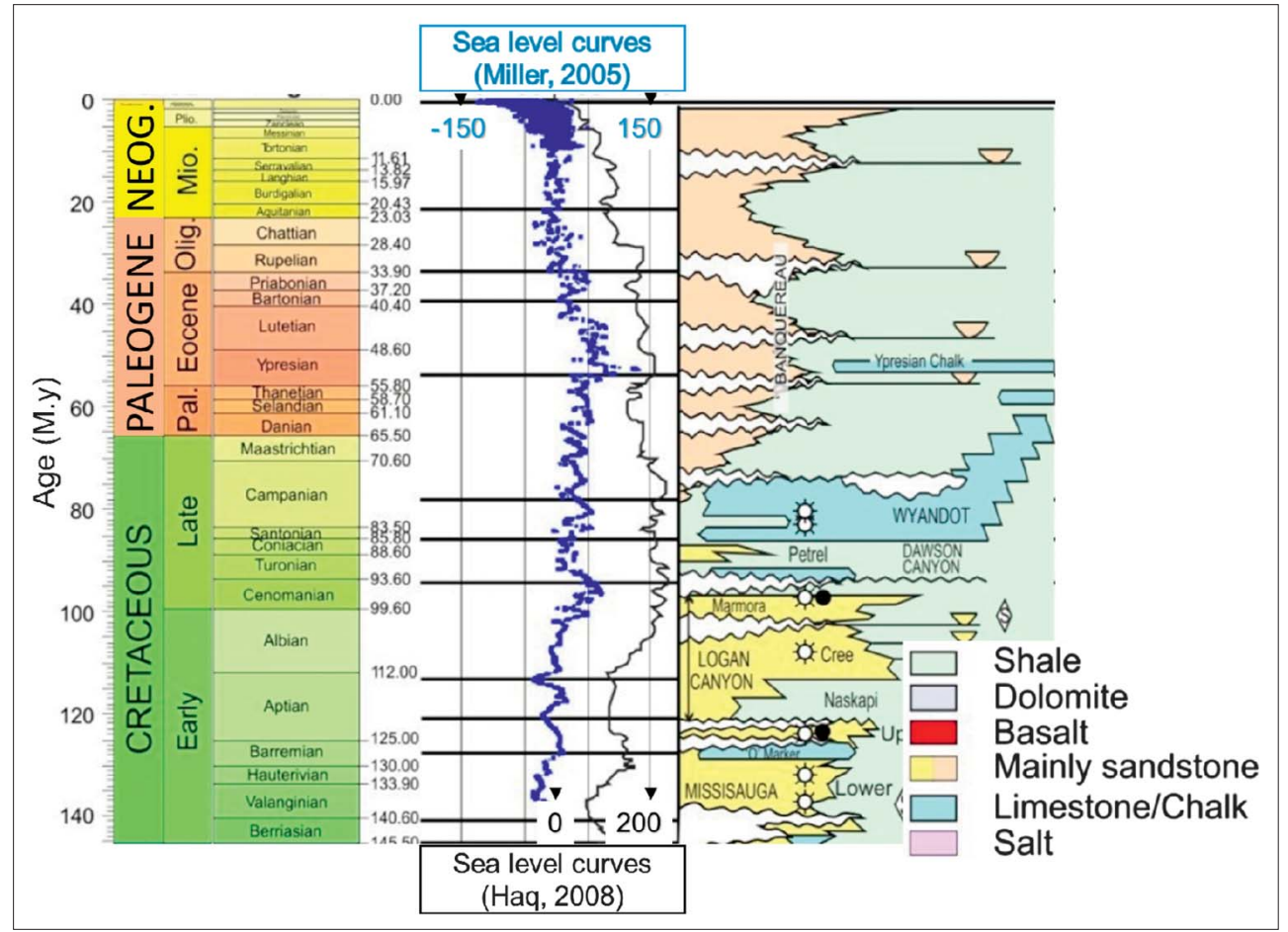

Figure 4: Lithostratigraphic column during the Cretaceous, Tertiary and Quaternary. Modified from Smith et al. (2010)

the 1200 m-thick formation of Logan Canyon at the top of the Mississauga Formation.

At the end of the Cretaceous in the Nova Scotia Basin, an increase in the sea level was observed, subsidence of the basin and the deposit of limestones of the Wyandot Formation. This surface shows evidence of a massive transport system that reworked the limestone and moved it towards the basin as described by Smith et al. (2010). This limestone comprises the Eagle gas field in parcel 9, although there is no evidence of mass transportation processes within the section at this location. The sediments of the Cenozoic located upon the Wyandot Formation form the Banquereau formation deposited as a progradational system of mudstones, loams and sandstones in relatively deep waters (see Figure 4).

\section{Methodology}

All the data worked in this research consisted in two wells (L-30 and B-41) and a seismic cube which was reduced because the acquisition area of the seismic cube is larger than the problem area, having, finally, a seismic subvolume with an area of $16 \mathrm{Km}^{2}$ (4 km x $4 \mathrm{~km}$ ) (see Figure 5).

\subsection{Seismic-Well Tie}

To correlate better the seismic data and the well information, it is necessary to have a good calibration at the reflectors of interest and, in this way, the data can be correlated in time (seismic) with those that are in depth

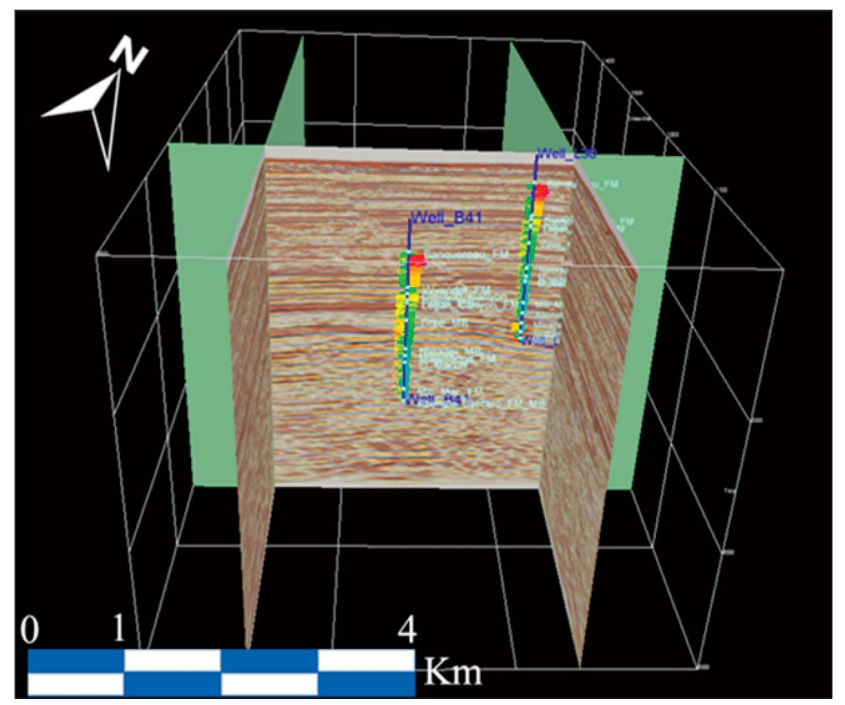

Figure 5: Seismic subvolume used and positions of the wells

(well data) and allow the transfer of the well properties to seismic data (Gaćeša \& Mesić, 1996). The first step was to extract the wavelet from the seismic data using the entire subvolume, getting an average wavelet (see Figure 6) to be used for both wells. After, using the sonic and density logs, the reflectivity series has been obtained. Convolution with the extracted wavelet resulted in the synthetic seismogram and subsequently, by means of the interpretation of these results, obtaining information from the seismic reflectors of interest (Red dotted on Figure 7). It should be noted that this was done for both wells (see Figure 8 and Figure 9). 
Figure 6: Extracted wavelet
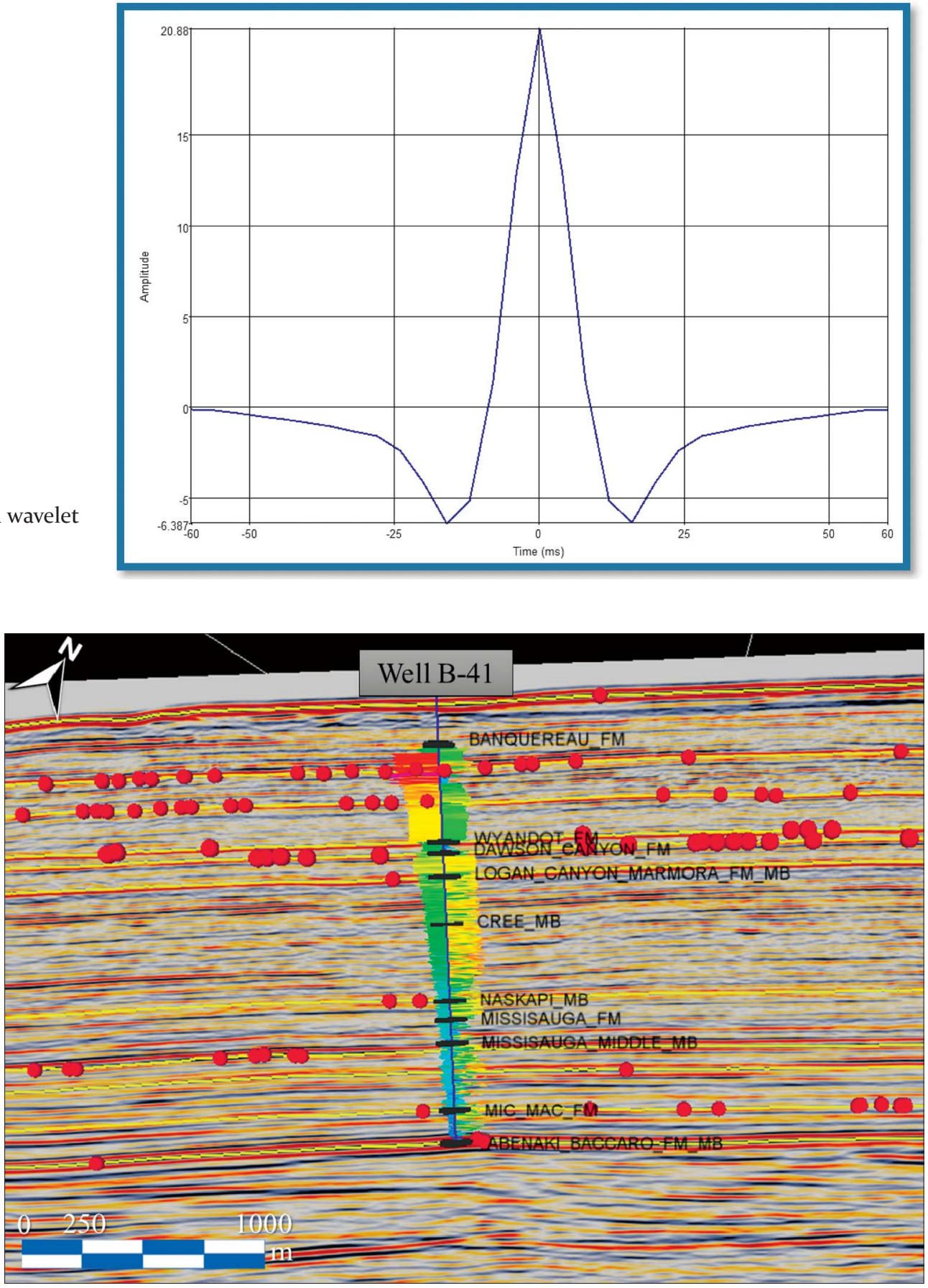

Figure 7: Well B-41 after being calibrated with the seismic

\subsection{Interpretation of seismic horizons}

Before applying the seismic attributes, some seismic horizons of interest were interpreted, in order to be able to notice if some structural heights could be observed in the surroundings of the well B-41. For that reason, two markers of the Mississauga Formation were interpreted, both upper and middle, as well as the Mic-Mac and Abenaki formations, which are below it, in order to observe if there were still upheavals in the areas surrounding the B-41 well, which may be more notorious due to hauling systematic error in travel times. On the other hand, the Naskapi Member and O-Marker were also in- terpreted, because the first is the foremost marker where the failure was noted in the travel times and the second because it is a regional marker in the Mississauga formation and their position in the well B-41 can be noted in Figure 7.

\subsection{Analysis using seismic attributes and multi-attributes by neural network}

Before doing this step, by means of well-log analysis, the anomalous region was identified and vertically we proceeded to apply the different seismic attributes at $936 \mathrm{~ms}$ because this is the time which corresponded to 


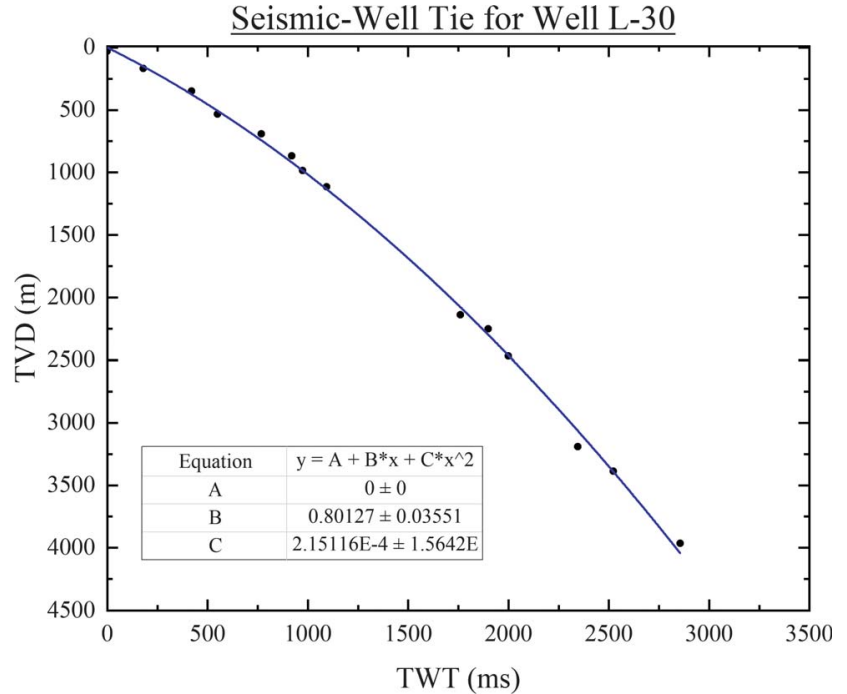

Figure 8: Seismic-Well Tie for Well L-30

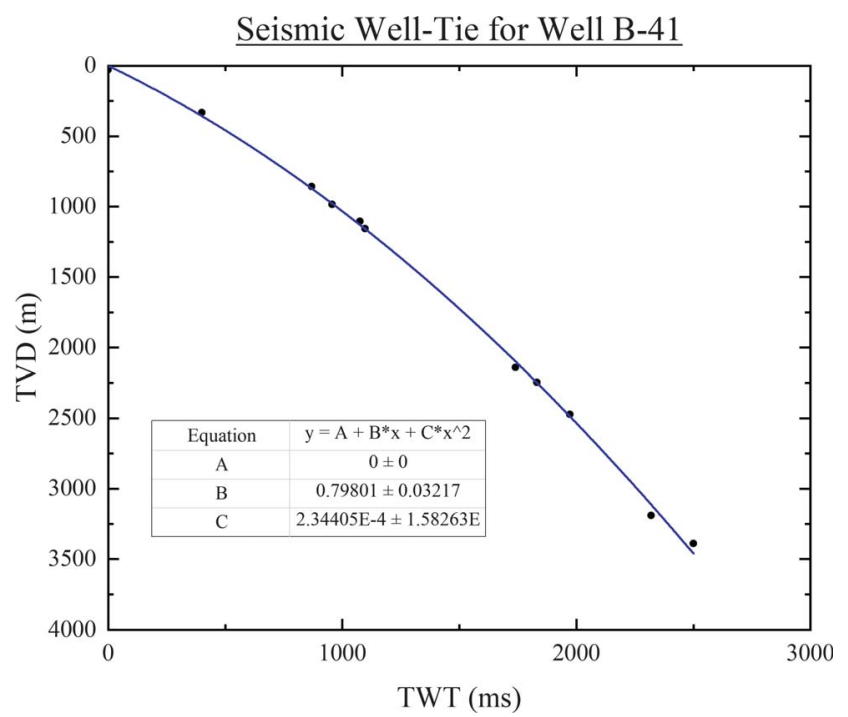

Figure 9: Seismic-Well Tie for Well B-41

Table 2: Seismic attributes tested, without doing integration among them

\begin{tabular}{|c|}
\hline Seismic attributes \\
\hline Energy \\
\hline Instant frequency \\
\hline Spectral decomposition $(110 \mathrm{~Hz})$ \\
\hline Semblance \\
\hline Instantaneous amplitude \\
\hline Acceleration of the phase \\
\hline
\end{tabular}

the location of the anomaly in travel time. It should be noted that a time window of $\pm 2 \mathrm{~ms}$ was used, since it is the minimum window corresponding to the thickness of the anomaly.

It was decided to apply the seismic attributes in three different ways and to conduct different tests about how
Table 3: Seismic attributes integrated by RGB

\begin{tabular}{|c|c|c|}
\hline \multicolumn{3}{|c|}{ Integration of attributes by RGB } \\
\hline $\begin{array}{c}\text { Blue } \\
\text { decompostral } \\
(110 \mathrm{~Hz})\end{array}$ & $\begin{array}{c}\text { Dreen } \\
\text { frequency }\end{array}$ & $\begin{array}{c}\text { Red } \\
\text { decompositral } \\
(23 \mathrm{~Hz})\end{array}$ \\
\hline $\begin{array}{c}\text { Acceleration of } \\
\text { the phase }\end{array}$ & $\begin{array}{c}\text { Cosine of the } \\
\text { phase }\end{array}$ & Energy \\
\hline $\begin{array}{c}\text { Instantaneous } \\
\text { frequency }\end{array}$ & $\begin{array}{c}\text { Cosine of the } \\
\text { phase }\end{array}$ & $\begin{array}{c}\text { Dominant } \\
\text { frequency }\end{array}$ \\
\hline Energy & $\begin{array}{c}\text { Instantaneous } \\
\text { amplitude }\end{array}$ & Semblance \\
\hline Energy & $\begin{array}{c}\text { Instantaneous } \\
\text { amplitude }\end{array}$ & $\begin{array}{c}\text { Instantaneous } \\
\text { Frequency }\end{array}$ \\
\hline $\begin{array}{c}\text { Spectral } \\
\text { decomposition } \\
(110 \mathrm{~Hz})\end{array}$ & Energy & $\begin{array}{c}\text { Instantaneous } \\
\text { Amplitude }\end{array}$ \\
\hline
\end{tabular}

Table 4: Seismic attributes integrated by neural network

\begin{tabular}{|c|c|}
\hline \multicolumn{2}{|c|}{ Attribute integration by neural networks } \\
\hline $\begin{array}{c}\text { Spectral decomposition of all } \\
\text { frequencies every } 10 \mathrm{~Hz} \text { from } \\
10 \mathrm{~Hz} \text { to } 120 \mathrm{~Hz}\end{array}$ & $\begin{array}{c}\text { Dominant frequency, } \\
\text { Instantaneous frequency, } \\
\text { Cosine of the phase and } \\
\text { Acceleration of the phase }\end{array}$ \\
\hline $\begin{array}{c}\text { Energy, Logarithm of energy, } \\
\text { Dominant frequency and } \\
\text { instantaneous amplitude }\end{array}$ & $\begin{array}{c}\text { Energy, instantaneous } \\
\text { amplitude, event and texture }\end{array}$ \\
\hline $\begin{array}{c}\text { Dominant frequency, } \\
\text { Instantaneous frequency, } \\
\text { Cosine of the phase, } \\
\text { Acceleration of the phase } \\
\text { and Spectral decomposition } \\
(23 \mathrm{~Hz}, 30 \mathrm{~Hz}, 10 \mathrm{~Hz} \text { and } \\
110 \mathrm{~Hz})\end{array}$ & $\begin{array}{c}\text { Spectral decomposition } \\
(120 \mathrm{~Hz}, 121 \mathrm{~Hz}, 122 \mathrm{~Hz}, \\
123 \mathrm{~Hz} \text { and } 124 \mathrm{~Hz})\end{array}$ \\
\hline
\end{tabular}

Table 5: Seismic attributes integrated by neural network and RGB

\begin{tabular}{|c|c|c|}
\hline \multicolumn{3}{|c|}{ Integration of attributes by RGB } \\
\hline Blue & Green & Red \\
\hline $\begin{array}{c}\text { Dominant } \\
\text { frequency, } \\
\text { Instantaneous } \\
\text { frequency, Cosine } \\
\text { of the phase and } \\
\text { Acceleration of } \\
\text { the phase }\end{array}$ & $\begin{array}{c}\text { Spectral } \\
\text { decomposition of } \\
\text { all frequencies } \\
\text { every } 10 \mathrm{~Hz} \text { from } \\
10 \mathrm{~Hz} \text { to } 110 \mathrm{~Hz}\end{array}$ & $\begin{array}{c}\text { Energy, Logarithm } \\
\text { of energy, } \\
\text { Dominant } \\
\text { frequency and } \\
\text { instantaneous } \\
\text { amplitude }\end{array}$ \\
\hline $\begin{array}{l}\text { Spectral } \\
\text { decomposition of } \\
\text { all frequencies } \\
\text { every } 10 \mathrm{~Hz} \text { from } \\
10 \mathrm{~Hz} \text { to } 110 \mathrm{~Hz}\end{array}$ & $\begin{array}{l}\text { Energy, } \\
\text { Semblance and } \\
\text { Similarity }\end{array}$ & $\begin{array}{c}\text { Dominant } \\
\text { frequency, } \\
\text { Instantaneous } \\
\text { frequency, Cosine } \\
\text { of the phase and } \\
\text { Acceleration of the } \\
\text { phase and Spectral } \\
\text { decomposition } \\
\text { (23Hz } 10 \mathrm{~Hz} 30 \mathrm{~Hz} \\
\text { and } 110 \mathrm{~Hz})\end{array}$ \\
\hline
\end{tabular}


the surface in time is seen when using specific attributes. The first way was through the use of seismic attributes without integration (see Table 2). Later an integration of attributes by RGB was made (see Table 3) through the mixtures of colours to obtain information that perhaps was not observable applying only a single attribute. Finally, seismic attributes of a similar nature were integrated by means of neural networks (see Table 4) and, in

Table 6: Meaning of every colour for every track for both wells

\begin{tabular}{|c|c|c|c|}
\hline Track 1 & Track 2 & Track 3 & Track 4 \\
\hline \multirow[b]{3}{*}{ Gamma Ray } & Vsh G. Ray & \multirow{2}{*}{$\frac{\text { Фeffec. MN }}{\Phi \text { effec Den-Neu }}$} & $\Phi \mathrm{MN}$ \\
\hline & Vsh Neu-Son & & $\Phi$ Den-Neu \\
\hline & Vsh MN & Фeffec. Den & $\Phi$ Den \\
\hline & Vsh Den-Neu & Фeffec. Son & $\Phi$ Son \\
\hline & Vsh Average & & \\
\hline
\end{tabular}

this way, more precise results were obtained and in addition to the last step, the attributes were conjugated by neural networks through an integration of RGB (see Table 5), thus having four forms of the seismic attributes use. The attributes used were chosen as those that depended on the frequency and amplitude.

\section{Results}

\subsection{Well-Log analysis at the Wyandot Formation}

The first step was to correct the data at the Wyandot Formation for well B-41, since the logging was done as sand matrix calibration, while this formation is carbonate. In the L-30 well it was not necessary because the logs were run with the correct matrix (carbonate matrix) in this region.

To delimit vertically the anomalous region at the Wyandot Formation, it was proceeded to correlate the information between the wells (B-41 and L-30) making calculations of the clay volumes using different logs: gam-

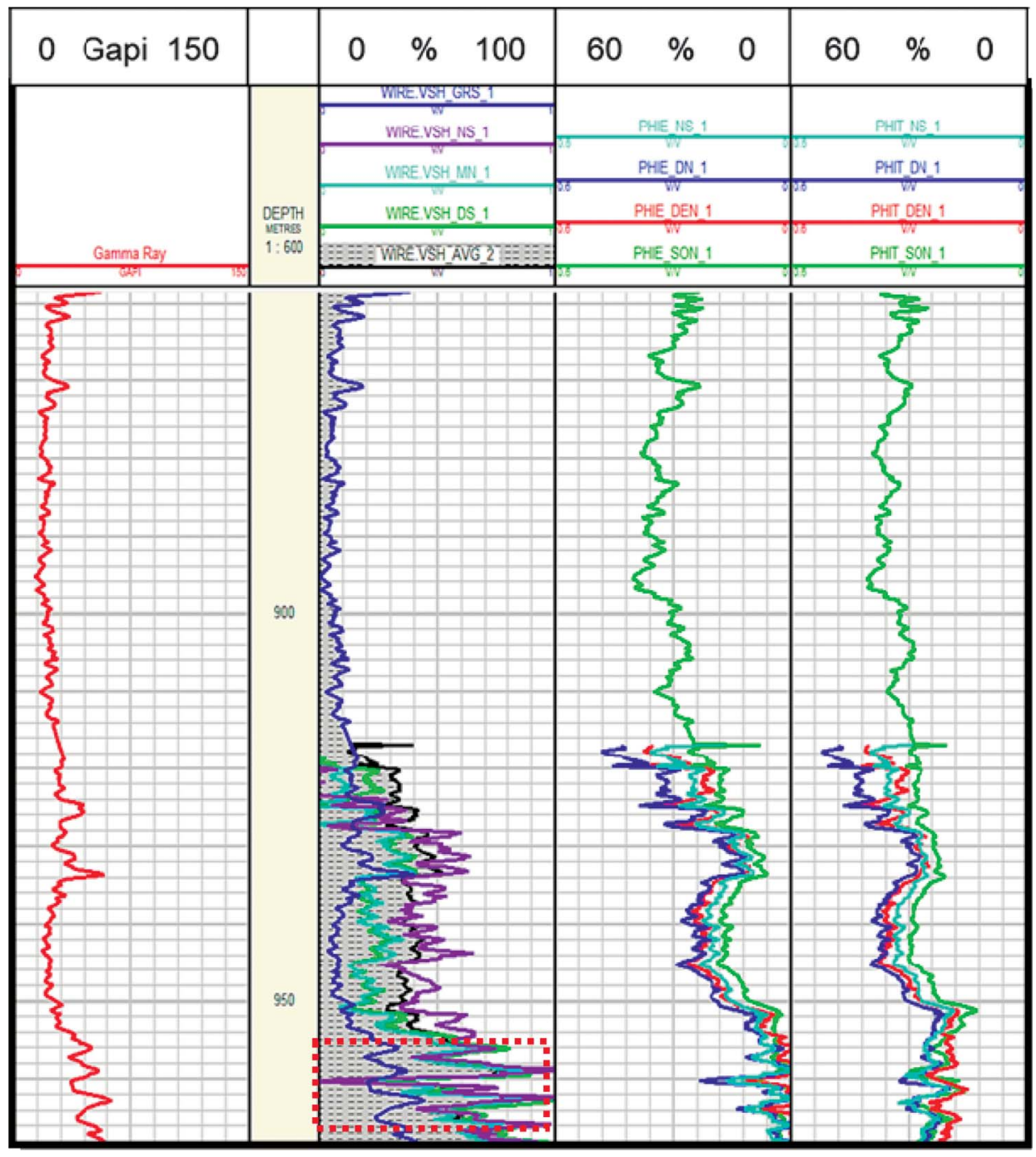

Figure 10: Logs from well B-41 for the Wyandot Formation and the red dotted line is the anomalous region 


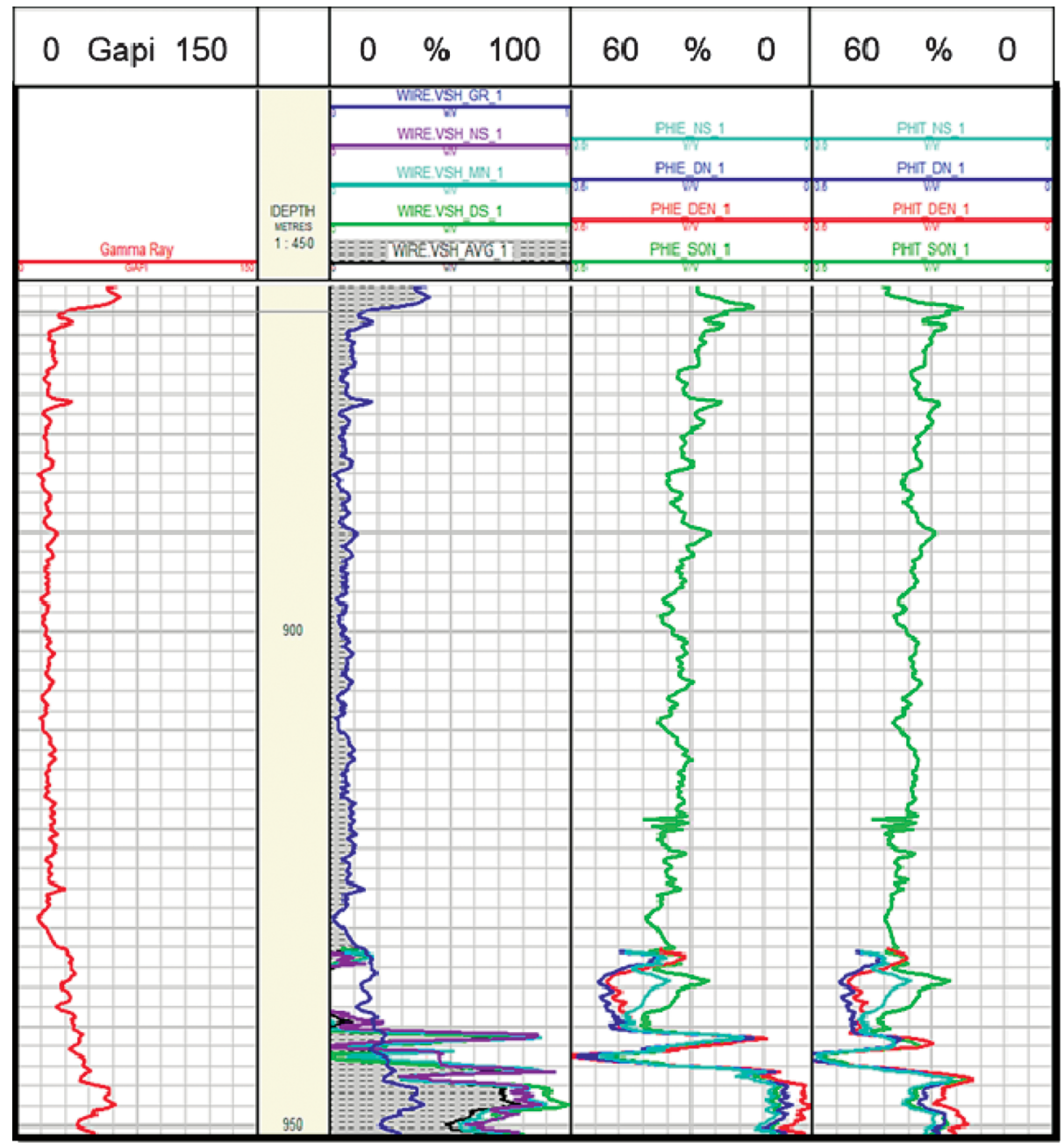

Figure 11: Logs from well L-3o for the Wyandot formation

ma ray, neutron porosity, sonic-neutron porosity, sonic-density and the clay volume average. In the same way, the calculations of total and effective porosities have been done, using the neutron and density logs, as well as the sonic log. These logs for both wells were displayed, in four tracks (see Figure 10 and Figure 11) and the legend of each record by tracks ( $1^{\text {st }}$ : Gamma Ray, $2^{\text {nd }}$ : Clay volume, $3^{\text {rd }}$ : Effective porosity; $4^{\text {th }}$ : Total porosity) is observable in Table 6.

Observing both records, it is clearly noted that for the well B-41, at a certain depth, the volume of clay presents a large increase, causing, at the same time, a decrease in the effective porosity and, also the total porosity decreases. All of the above could be due to a tight carbonate which increases the average velocity and reduces the porosity. On the other hand, in the L-30 well, it can be seen that it is a very clean limestone, with a greater porosity, both effective and total. All this led the summarized properties for both wells in Table 7 and the anomalous region (red dotted line in Figure 10) which was noticed as an alteration in the logs, as it was shown before, having an interpreted thickness of about $12.32 \mathrm{~m}$ at a depth of $956 \mathrm{~m}$.
Table 7: Summary of properties between both wells and the anomaly

\begin{tabular}{|l|l|l|l|}
\hline \multirow{2}{*}{ Property } & Well B-41 & Well B-41 & Well L-30 \\
\cline { 2 - 4 } & Anomaly & Wyandot & Wyandot \\
\hline Top (m) & 956.06 & 859.49 & 867.42 \\
\hline Base (m) & 968.38 & 968.38 & 951.91 \\
\hline Thickness (m) & 12.32 & 108.73 & 84.64 \\
\hline Velocity (m/s) & 3115 & 2887 & 2836 \\
\hline $\begin{array}{l}\text { VSh by Gamma Ray } \\
\text { (v/v) }\end{array}$ & 0.107 & 0.106 & 0.101 \\
\hline $\begin{array}{l}\text { Gamma Ray by Sonic } \\
\text { (GAPI) }\end{array}$ & 25.70 & 25.63 & 24.29 \\
\hline $\begin{array}{l}\text { Porosity by sonic } \\
\text { (v/v) }\end{array}$ & 0.197 & 0.287 & 0.356 \\
\hline $\begin{array}{l}\text { Effective porosity } \\
\text { by sonic (v/v) }\end{array}$ & 0.080 & 0.248 & 0.312 \\
\hline
\end{tabular}

After having delimited the anomaly vertically in well B-41, it is necessary to compare this value with the seismic resolution, for this we refer to Campbell et al., (2015) who stated that a fundamental frequency of $25 \mathrm{~Hz}$ for the seismic-well tie is ideal, which results in a resolu- 

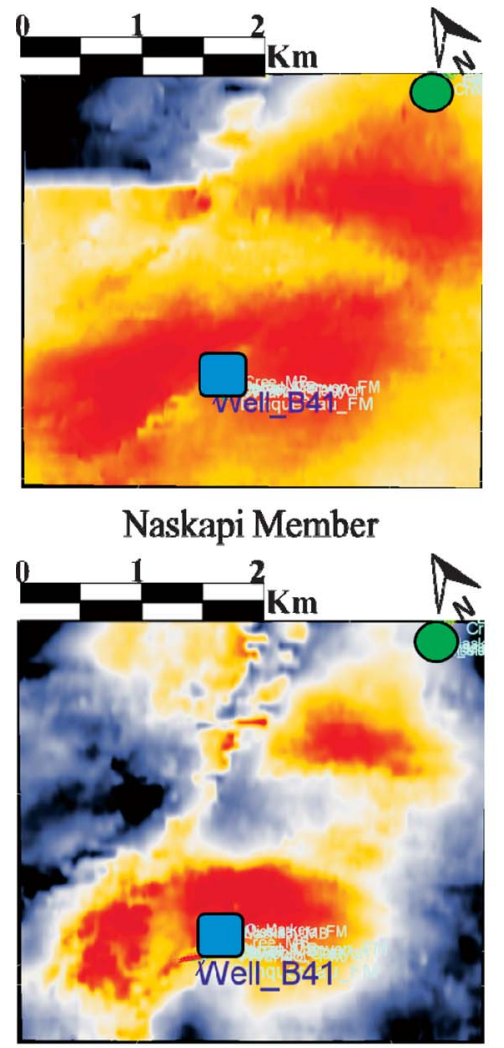

Fm. Middle Missisauga

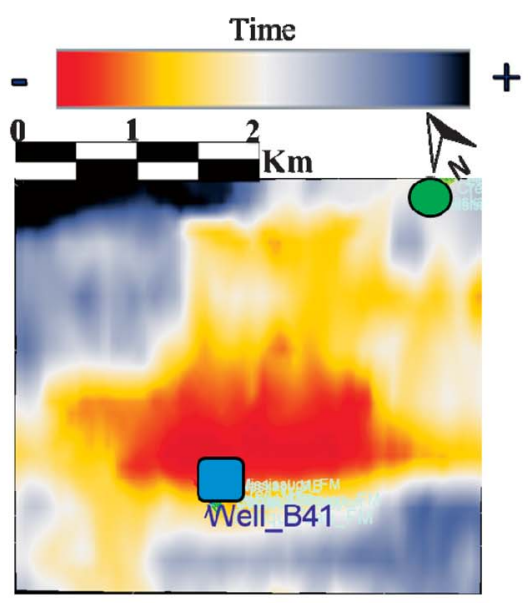

Fm. Missisauga (Top)

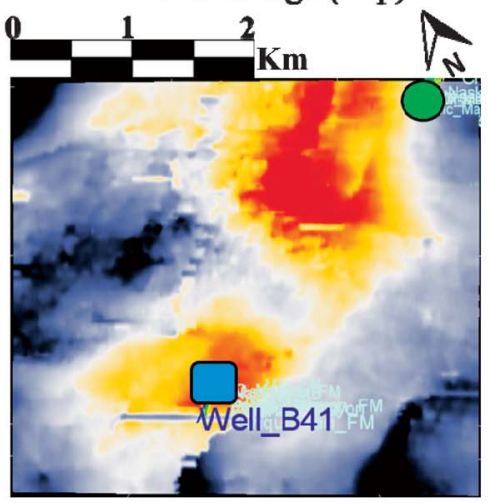

Fm. Mic-Mac

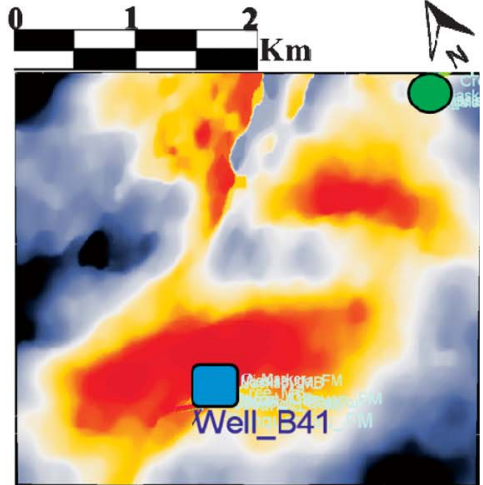

O-Marker Member

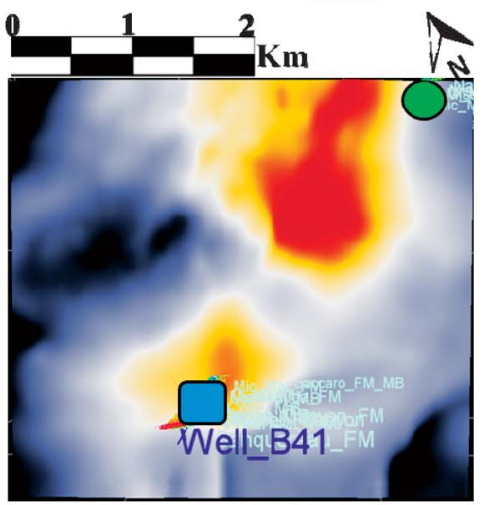

Fm. Abenaki

Figure 12: Interpreted seismic surfaces (Blue square: Well B-41; Green circle: Well L-30)

tion in the anomalous region of approximately $31 \mathrm{~m}$. On the other hand, Sayers (2013) indicated that throughout the cube, variations in vertical resolution ranging from $21 \mathrm{~m}$ to $61 \mathrm{~m}$ can be observed. Therefore, based on this information, the thickness of the anomaly is smaller than the vertical resolution and, additionally, remembering that it is a marine seismic, this causes high frequencies to be lost very superficially since the water column causes this effect (Haesang, et al., 2018).

\subsection{Interpretation of seismic horizons}

Interpretations of six relevant seismic markers were performed (see Figure 12), in order to notice if any structural high was observed in the vicinity of well B-41 in the strata inferior to the Wyandot formation. The surfaces presented in Figure $\mathbf{1 2}$ are ordered according to their depth with Naskapi being the shallowest and Abenaki the deepest. In them, you can see by means of the colour scale (red: closer to the surface, blue: deeper) that the area surrounding the well B-41 is higher, however, as it goes deeper, it is noted that there is only one feature in the region of the well B-41 that does not disappear. All this already gives a signal that is always going to observe a time closer to the surface in the vicinity of the well.

\subsection{Analysis using seismic attributes and multi-attributes by neural network}

Having vertically delimited an anomalous behaviour in the Wyandot formation in well B-41, the seismic attributes were displayed and observed (see Figure 13), tendencies are noted around well B-41 and they were marked with dotted lines of white colour, however, it is not a consistent area in each attribute test, in fact, until there is an attribute (Spectrum decomposition at $110 \mathrm{~Hz}$ ) that does not present a trend similar to the other five, so we will continue with the tests integrating them by RGB.

When performing the integration of attributes through the use of RGB (see Figure 14), it is observed that the trends are more uniform in terms of geometry, however, the results are more clearly noticed than the first ones. Seismic attribute tests, that is why we wanted to continue testing while using more complex mechanisms, which reaffirmed the earlier observations, which in this case is through a multi-attribute analysis by neural networks.

To do the analysis by neural networks using seismic attributes, every group of attributes had the same origin (for example: those depending on frequency or amplitude). Every test consisted of a multilayer feed forward network because it was a series of seismic attributes as 


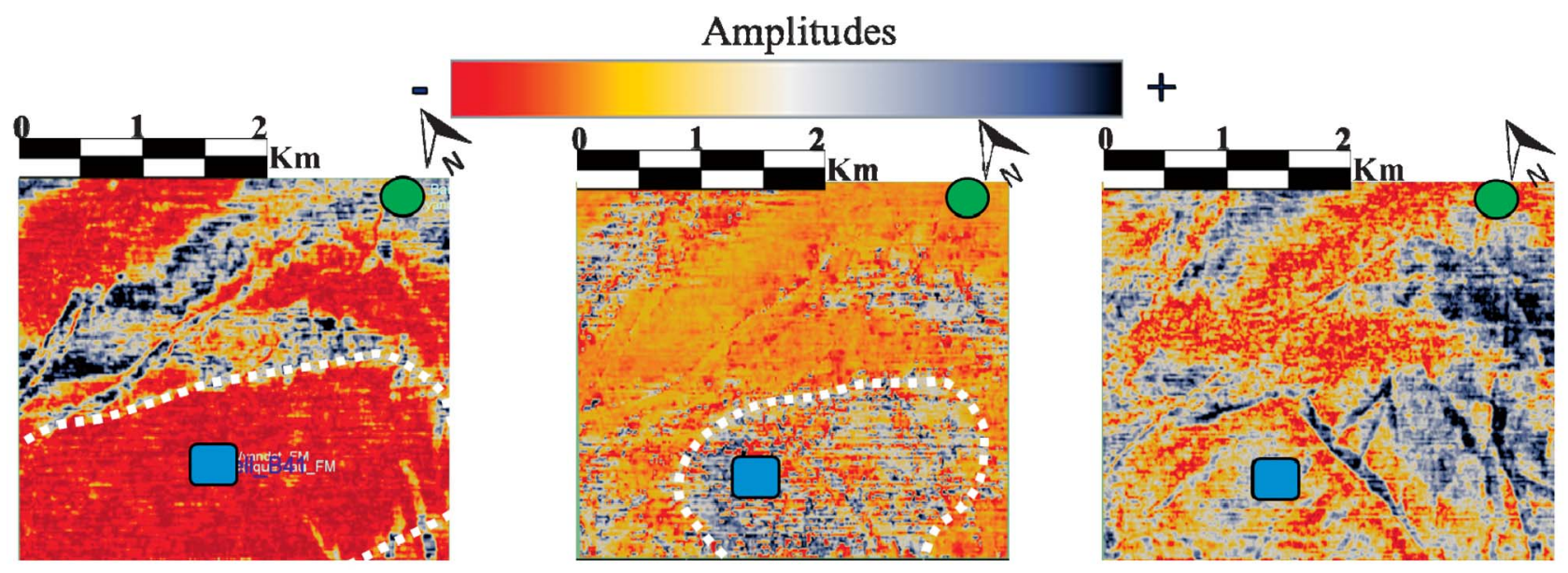

Energy

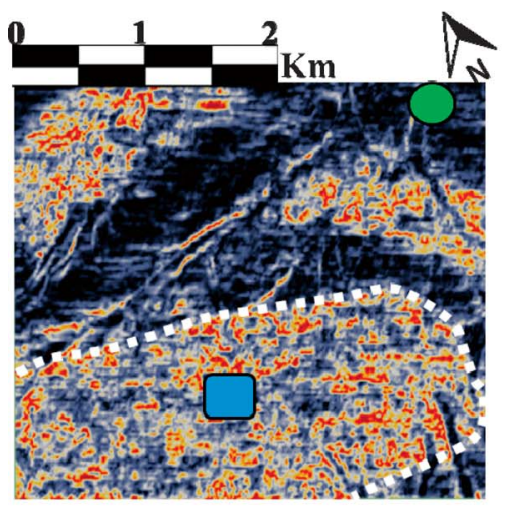

Semblance
Instantaneous frequency

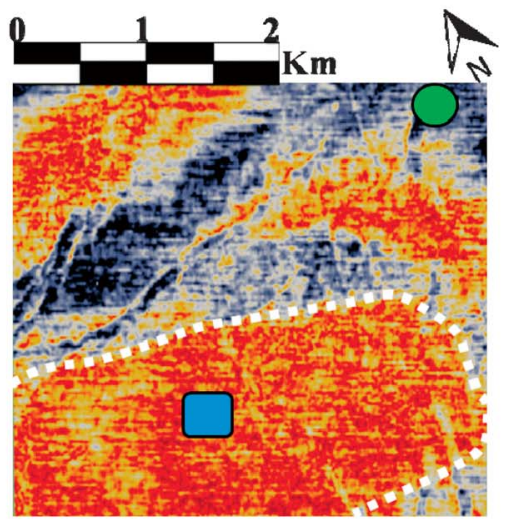

Instantaneous amplitude
Spectral decomposition at $110 \mathrm{~Hz}$

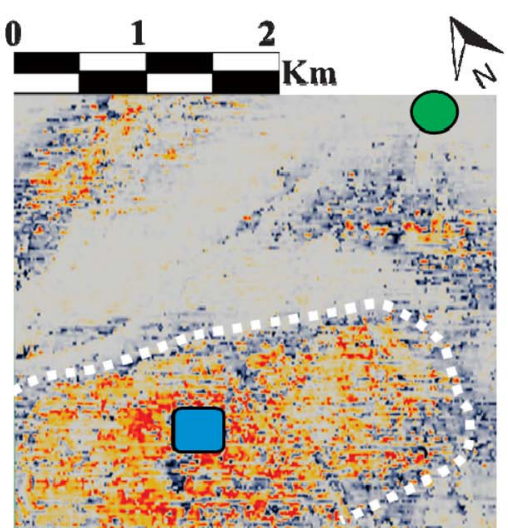

Phase acceleration

Figure 13: Seismic attributes without integration between them (Blue square: Well B-41, Green circle: Well L-30)

input (see Table 5) with an output (see Figure 15) and all these tests were run for a maximum number of classes of 10 with no training algorithm, also the results using seismic multi-attributes depend on the quality of the seismic signal (Malvić et al. 2009).

Through the use of neural networks (see Figure 15), we note the number of classes in the different points of the surfaces in time and regardless of whether this number is from one end or the other, the same tendency is always appreciated, having as the best results, where everything is observed more clearly, in those integrations of attributes of the same nature, for example, when only those of spectral decomposition or those dependent on energy in seismic survey are used. That is why, having these results, we wanted to conjugate them through integration by RGB and, thus, obtain the definitive tendencies.

When performing the integration of multi-attributes of neural networks by RGB (see Figure 16) the last confirmation and the definitive answer of what the seismic anomaly could be and that varied its area in the previous tests were obtained. However, here it is observed that, in spite of combining different types of attributes, both responses were the same, and this may give way to delimit in a more precise way.
Having done all the tests, one of the multi-attribute surfaces integrated by RGB (the surface located to the right in Figure 16) was taken to quantitatively obtain the dimensions of the possible observable anomaly in the vicinity of well B-41 in the Wyandot formation (see Figure 17). This type of high velocity anomaly affects the travel times of the waves even at CMP sorting at the moment of seismic processing, eventually resulting in false structural heights, as illustrated in Figure 18, where it is perceived as the travel of the waves go through a high velocity anomaly, having that those waves that travel through the anomaly are going to have a shorter travel time, consequently a false height is observed

In addition to everything shown before, the best results using only one seismic attribute were energy and instantaneous amplitude. In this way, the best results were received integrating attributes by neural network by means of those attributes depending on amplitude and energy as shown in Figure 15 (energy, logarithm of energy, dominant frequency and instantaneous amplitude) (energy, instantaneous amplitude, event and texture). Also, the neural networks could be used in this zone in future works to predict the difference in lithology (Šapina, 2016). 


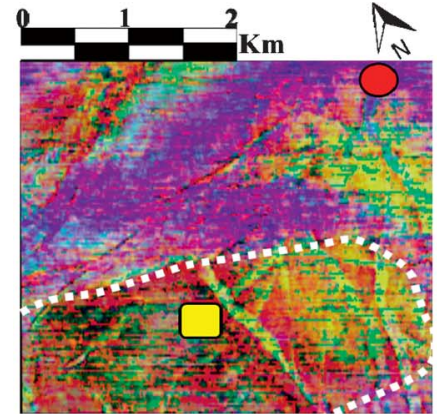

Spectral decomposition $(110 \mathrm{~Hz})$,

Dominant frequency and Spectral decomposition $(23 \mathrm{~Hz})$

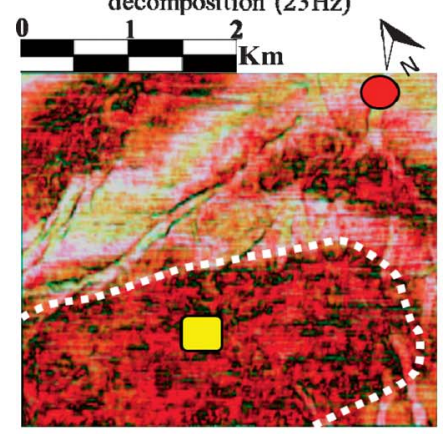

Energy, Instantaneous amplitude and Semblance

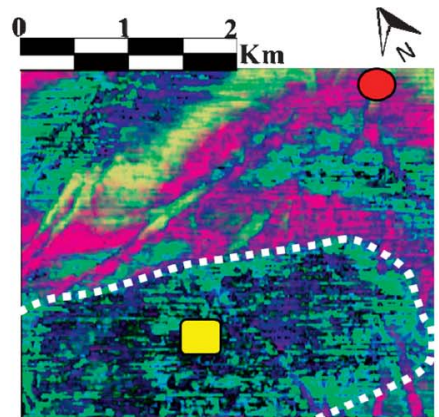

Acceleration of the phase, Cosine of the phase and Energy

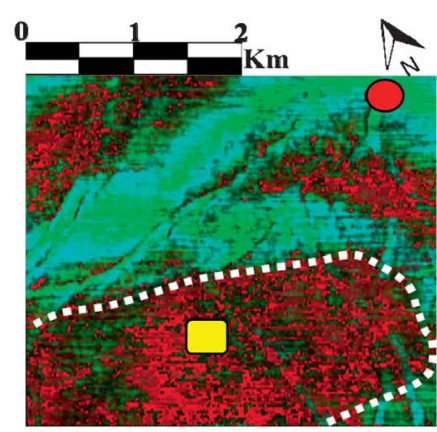

Energy, Instantaneous amplitude and Instantaneous Frequency

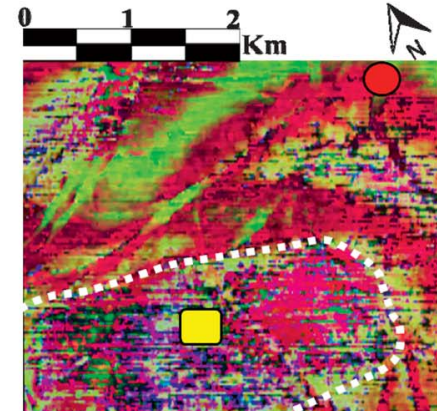

Instantaneous frequency, Cosine of the phase and Dominant frequency

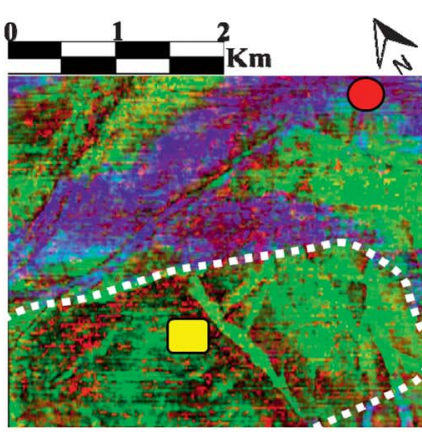

Spectral decomposition $(110 \mathrm{~Hz})$,

Energy and Instantaneous Amplitude

Figure 14: Integration of seismic attributes by RGB (Yellow square: Well B-41, Red circle: Well L-30

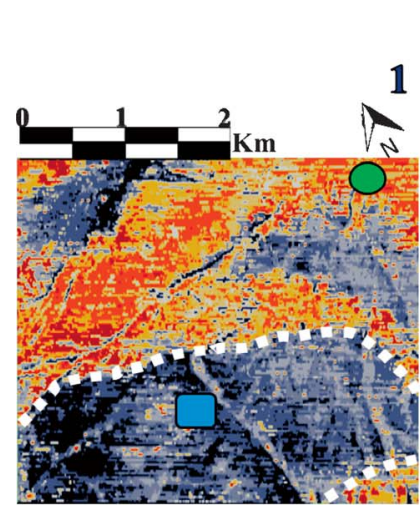

Spectral decomposition of all frequencies every $10 \mathrm{~Hz}$ from $10 \mathrm{~Hz}$ to $120 \mathrm{~Hz}$

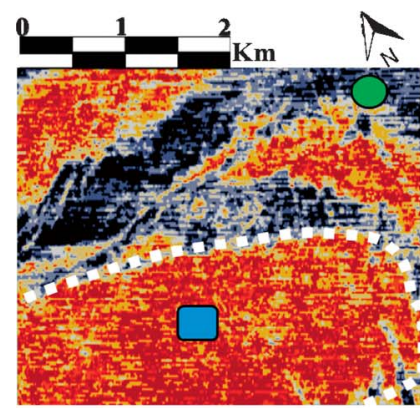

Energy, instantaneous amplitude, event and texture
Number of classes

\section{,}

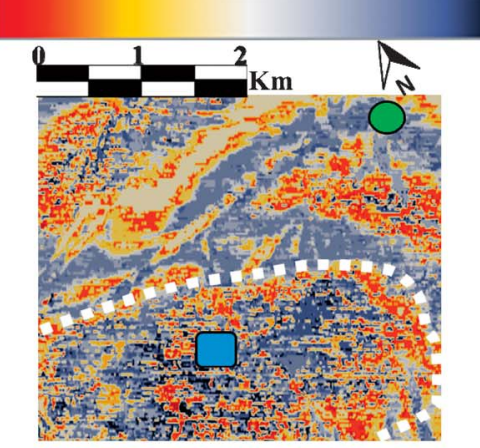

Dominant frequency,

Instantaneous frequency, Cosine of the phase and Acceleration of the phase

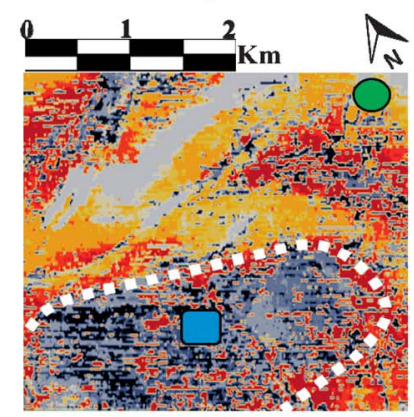

Dominant frequency,

Instantaneous frequency, Cosine of the phase, $\Lambda$ cceleration of the

phase and Spectral decomposition

$(23 \mathrm{~Hz}, 30 \mathrm{~Hz}, 10 \mathrm{~Hz}$ and $110 \mathrm{~Hz})$
10

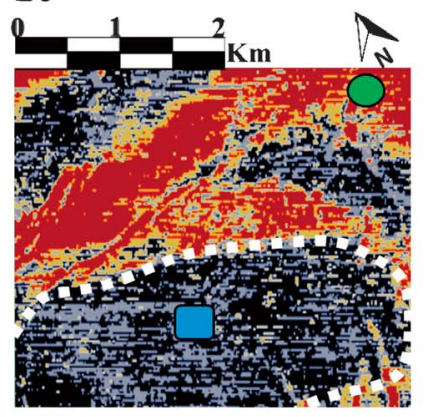

Energy, Logarithm of energy, Dominant frequency and instantaneous amplitude

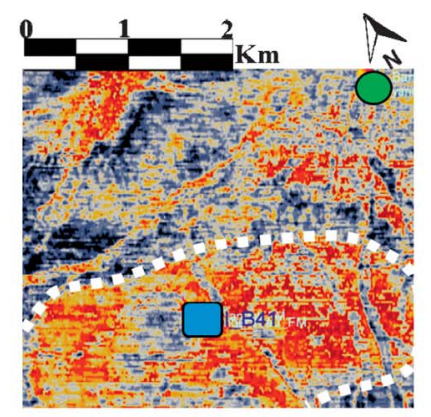

Spectral decomposition $(120 \mathrm{~Hz}$, $121 \mathrm{~Hz}, 122 \mathrm{~Hz}, 123 \mathrm{~Hz}$ and $124 \mathrm{~Hz})$

Figure 15: Multi-attribute analysis by neural networks (Blue square: Well B-41, Green circle: Well L-30) 


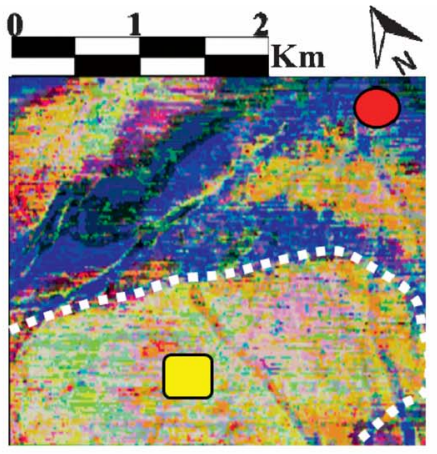

Dominant frequency, Instantaneous frequency, Cosine of the phase and Acceleration of the phase, Spectral decomposition of all frequencies every $10 \mathrm{~Hz}$ from

$10 \mathrm{~Hz}$ to $110 \mathrm{~Hz}$, Energy, Logarithm of energy,

Dominant frequency and instantaneous amplitude

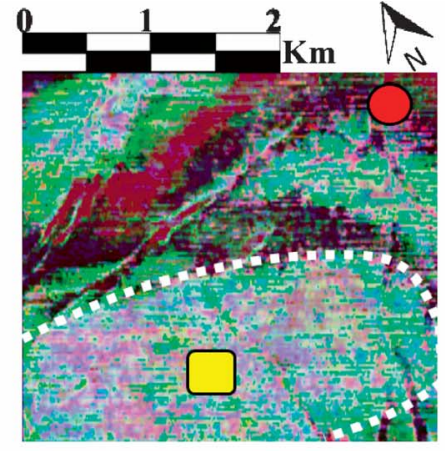

Spectral decomposition of all frequencies every $10 \mathrm{~Hz}$ from $10 \mathrm{~Hz}$ to $110 \mathrm{~Hz}$, Energy, Semblance and Similarity,

Dominant frequency, Instantaneous frequency, Cosine of the phase and Acceleration of the phase and Spectral decomposition $(23 \mathrm{~Hz} 10 \mathrm{~Hz} 30 \mathrm{~Hz}$ and $110 \mathrm{~Hz})$

Figure 16: Multi-attribute analysis by neural networks using RGB integration (Yellow square: Well B-41, Red circle: Well L-30)

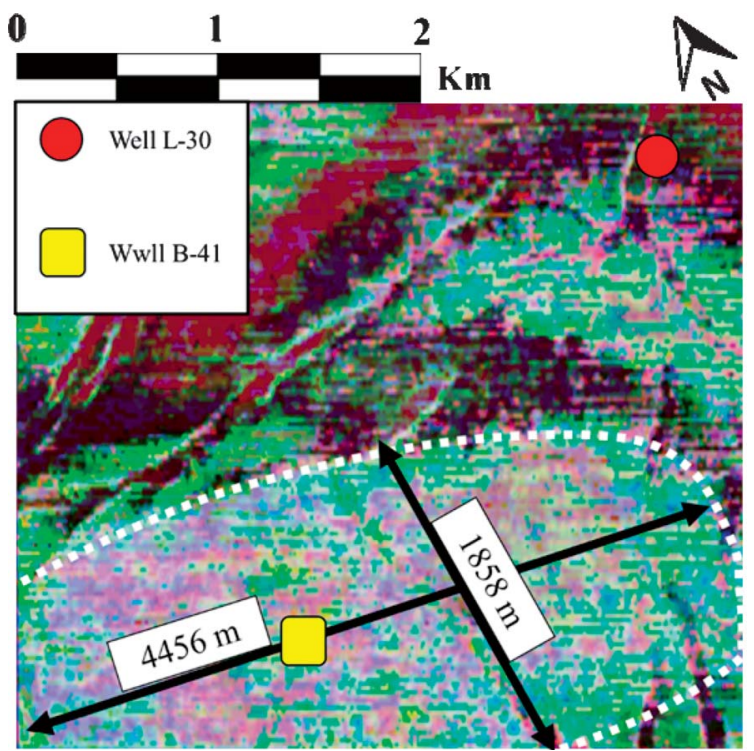

Figure 17: Anomaly laterally delimited

\section{Conclusions}

The remarkable conclusion is that by means of a good integration of seismic attributes and petrophysical data, supported by non-linear classification algorithms, it is possible to find bodies that are imperceptible to the vertical seismic resolution, as was shown in the results.

Using the well-log information, a region inside in the well B-41 was delimited vertically, which was supposed as a tight carbonate that caused the discrepancy in the travel time. On the other hand, it was verified that the region was thinner than the seismic resolution. For this reason, it is always very important to know the consequences of an imperceptible anomaly to the seismic resolution, in this way, if exploratory wells are available before a 3D acquisition project, it is necessary to study this data thoroughly, since it can give an indication of anomalous bodies which have to be taken into account at the moment of the processing of new seismic data.
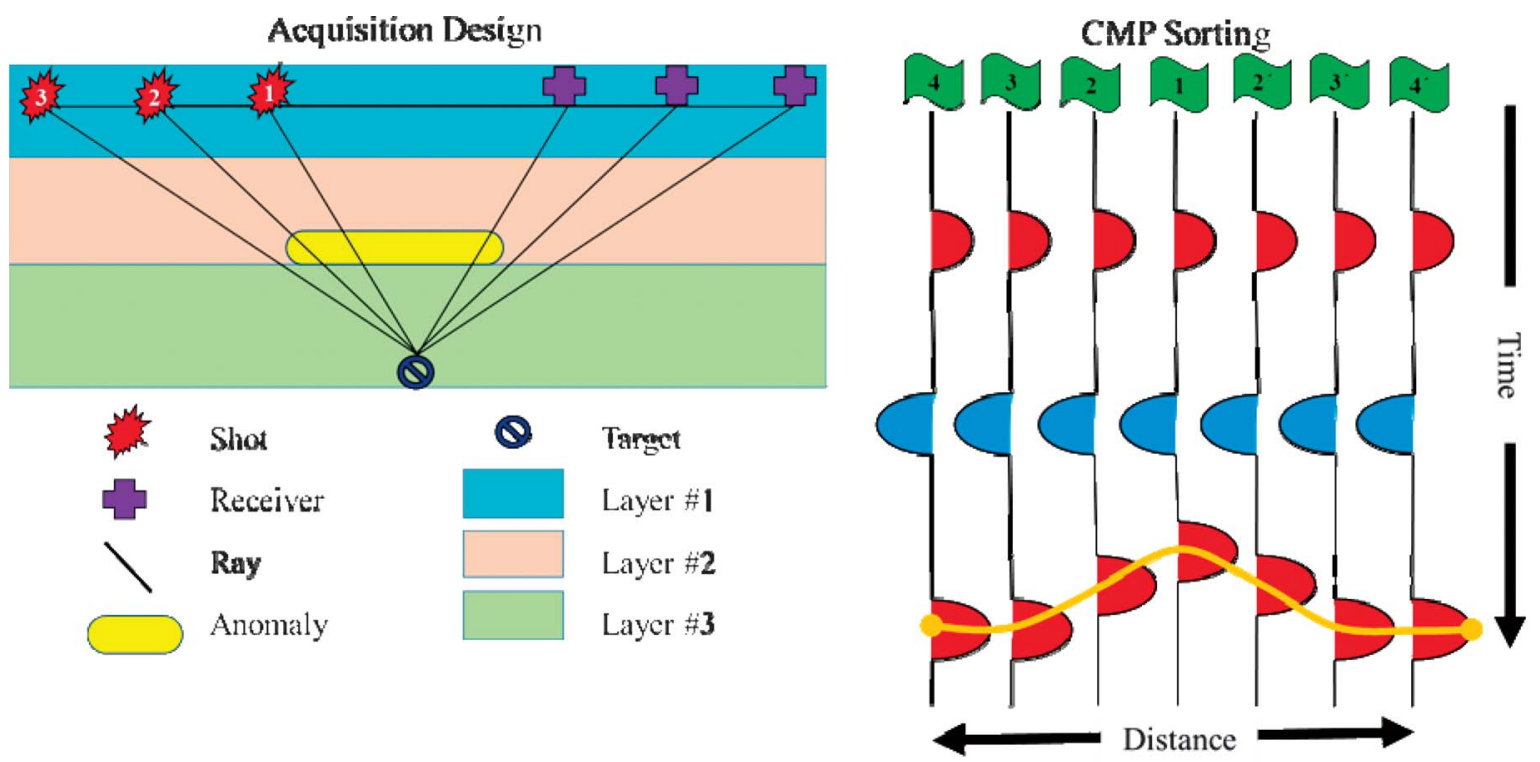

Figure 18: Example of travel of a wave crossing an anomalous body and its subsequent ordering by CMP 
With all the tests using seismic attributes, the affected region around well B-41 was able to be delimited and the best results were obtained by means of multi-attribute analysis by neural networks.

Finally, the results obtained in this research were satisfactory, which leads us to recommend this type of study to identify possible similar problems and it could be applied to those cases where the problem might be caused by a low velocity anomaly.

\section{References}

Albertz, M., Beaumont, C., Shimeld, J., Ings, S., and Gradmann, S. (2010): An investigation of salt tectonics structural styles in the Scotian Basin, offshore Atlantic Canada: 1. Comparison of observations with geometrically simple numerical models. Tectonics, 29, 4, 1-16. doi: 10.1029/2009TC002540

Alsadi, H. N. (2017): Seismic Hydrocarbon Exploration (Vol. 1). Springer International Publishing, 341 p., Basel. doi: 10.1007/978-3-319-40436-3

Campbell, T., Richards, F., Silva, R., Wach, G., and Eliuk, L. (2015): Interpretation of the Penobscot 3D seismic volume using constrained sparse spike inversion, Sable sub-Basin, offshore Nova Scotia. Marine and Petroleum Geology, 68(Part A), 73-93.

Gaćeša Slobodan and Mesić Ivan (1996): Seismic Line Calibration - A Main Reference for the Rational Exploration and Development of Very Complex Oil and Gas Fields and Reservoirs (Bizovacki Cret Case Study). Geologia Croatica 49(2).

Haesang Yang, Woojae Seong, Keunhwa Lee. (2018): Modeldata comparison of high frequency compressional wave attenuation in water-saturated granular medium with bimodal grain size distribution. Ultrasonics 82, 161-170.

Hansen, Møller D., Shimeld, J.W., Williamson, M.A., LykkeAnderse, H. (2004): Development of a major polygonal fault system in Upper Cretaceous chalk and Cenozoic mudrocks of the Sable Subbasin, Canadian Atlantic margin. Marine and Petroleum Geology, 21, 9, 1205-1219. DOI: 10.1016/j.marpetgeo.2004.07.004

Jansa, Lubomir F., Noguera Urrea, V.H. (1990): Geology and diagenetic history of overpressured Sandstone reservoirs, Venture Gas Field, offshore Nova Scotia, Canada. The American Association of Petroelum Geologist Bulletin, 74, 10, 1640-1658.

Kidston, A., Brown, D., Altheim, B., and Smith, B. (2002): Hydrocarbon potential of the deep-water Scotian Slope.
Nova Scotia: Canada-Nova Scotia Offshore Petroleum Board, 111 p., Halifax.

Malvić T., Barišić M., and Futivić I. (2009): Cokriging geostatistical mapping and importance of quality of seismic attribute(s). Nafta, 60, 5, 259-264.

McIver, N. (1972): Mesozoic and Cenozoic stratigraphy of the Nova Scotia Shelf. Canadian Journal of Earth Sciences, 9, 1, 54-70. https://doi.org/10.1139/e72-005

Pe-Piper, G., Mackay, M. (2006): Provenance of Lower Cretaceous sandstones onshore and offshore Nova Scotia from electron microscope geochronology and chemical variation of detrital monazite. Bulletin of Canadian Petroleum Geology, 54, 366-379.

Šapina Marijan (2016): A Comparison of Artificial Neural Networks and Ordinary Kriging depth maps of the Lower and Upper Pannonian stage border in the Bjelovar Subdepression, Northern Croatia. The Mining-Geology-Petroleum Engineering Bulletin (Rudarsko-geološko-naftni zbornik), 31, 3, 75-86. DOI: 10.17794/rgn.2016.3.6

Smith, B., Makrides, C., and Kendell, K. (2015): CNSOPB Geoscience Open File Report. Exploration history, geologic setting, and exploration potential: Eastern Region. Halifax, Nova Scotia: Canada-Nova Scotia Offshore Petroleum Board.

Wade, J., and MacLean, B. (1990): The geology of the southeastern margin of Canada, Chapter 5, Part 2: Aspects of the geology of the Scotian Basin from recent seismic and well data. In: Geology of the Continental Margin of Eastern Canada (eds. Keen, M.J. and Willians, G.L.), Geological Survey of Canada, 2, 167-238.

Welsink, H., Dwyer, J., and Knight, R. (1989): Tectono-stratigraphy of the passive margin of Nova Scotia. AAPG Memoir, 46, 215-231.

Weston, J.F., MacRae, R.A., Ascoli, P., Cooper, M.K.E., Fensome, R.A., Shaw, D. and Williams, G.L. (2012): A revised biostratigraphic and well-log sequence stratigraphic framework for the Scotian Margin, offshore eastern Canada. Can. J. Earth Sci., 49, 12, 1417-1462.

\section{Internet sources:}

Beicip-Franlab. (2011): Chapter 3: Stratigraphy. Play Fairway Analysis e Offshore Nova Scotia. Retrieved from: https:// energy.novascotia.ca/sites/default/files/files/CHAPTER_3 _Complete.pdf (accessed 31th July 2018)

Canada-Nova Scotia Offshore Petroleum Board. (n.d.): Regional Geology. URL: http://www.cnsopb.ns.ca/geoscience/geoscience-overview/regional-geology (accessed on April 17th, 2017) 


\section{SAŽETAK}

\section{Prepoznavanje anomalije prouzročene velikom brzinom seizmičkih valova (neopazive na skali seizmičke razlučivosti) integracijom seizmičkih svojstava, primjer polja Penobscot, Kanada}

Polje Penobscot nalazi se u podnožju Sable, u bazenu Nova Škotska koji pripada kanadskomu području, gdje je 1991. godine načinjeno 3D seizmičko snimanje. Prethodno su izbušene dvije istraživačke bušotine (L-3o i B-41). Zatim je, uz dodatnu interpretaciju, otkriveno vrijeme prolaska 10 do $15 \mathrm{~ms}$ (otprilike 25 metara) seizmičkih valova u blizini bušotina B-41, što je rezultiralo interpretacijom „lažnih” struktura unutar članova Missisauga i Naskapi. To je vjerojatno uzrokovano promjenama u sastavu i debljini Wyandotove formacije. Prepoznavanje uzroka lažnih signala bušotina B-41 dobro je izvedeno. Prepoznavanjem lažnih ocrta bilo je moguće područje između dviju spomenutih bušotina ocrtati kao seizmički podvolumen, odnosno kao dio „seizmičke kocke”. Time je seizmička interpretacija postala strukturno ispravna, uz dodatno omogućavanje analize određenih petrofizičkih svojstava u bušotinama. Nadalje, utvrđena je debljina područja „anomalnoga” odziva, kako po okomici tako i bočno, a unutar formacije Wyandot.

\section{Ključne riječi:}

seizmička anomalija brzina, formacija Wyandot, član Missisauga, član Naskapi, seizmički atributi

\section{Author contributions}

García M. Wilmer E. (Geophysical Engineer) led this research doing all the tests shown before and he wrote this paper. Omaña G. Iván D. (MSc. Earth Sciences) initialized the idea of this research, proportioning help to García, reading and making corrections in this paper before submitting. 